\title{
IMPLEMENTASI MODEL PEMBELAJARAN DARING PADA MASA PANDEMI COVID - 19
}

\author{
${ }^{1}$ Harmawati, ${ }^{2}$ Tia Latifatu Sa'diah, ${ }^{3}$ Nadiya Angraeni \\ 1,2,3 Program Studi Pendidikan Guru Sekolah Dasar, Fakultas Keguruan dan Ilmu Pendidikan \\ 1harmawati@ubpkarawang.ac.id 2tia.latifatu@ubpkarawang.ac.id \\ 3sd17.nadiyaangraeni@mhs.ubp.ac.id
}

\begin{abstract}
ABSTRAK
Penelitian ini merupakan penelitian kualitatif deskriptif. Penelitian ini dilaksanakan di Sekolah Dasar Negeri Cengkong II Kecamatan Purwasari kabupaten Karawang. Subjek penelitian ini adalah 3 orang yaitu guru kelas IV, 1 orang siswa dan 1 orangtua siswa. Objek penelitian ini adalah proses pembelajaran daring pada masa covid-19. Teknik pengumpulan data yang digunakan dalam penelitian ini adalah pengamatan dan wawancara. Instrumen pengumpulan data terdiri atas pengamatan dan pedoman wawancara. Analisis data dilakukan secara deskriptif dengan melakukan Teknik analisis data model Miles and Humberman.

Hasil dari pengamatan dan wawancara diperoleh bahwa Sekolah Dasar Negeri Cengkong II Kecamatan Purwasari Kabupaten Karawang pada masa pandemi covid-19 melakukan pembelajaran jarak jauh (PJJ) dengan menggunakan model pembelajaran daring / online. Aplikasi whatsapp, google meet, google form, zoom dan kine master adalah aplikasi yang digunakan dalam proses pembelajaran daring / online. Handphone, kuota dan jaringan internet yang kuat dan stabil merupakan faktor utama dalam proses pembelajaran daring / online, agar tercapainya materi ajar dan tujuan pembelajaran selama guru menjelaskan dan menyampaikan materi yang telah disiapkan. Selain itu terdapat kendala dalam proses pembelajaran daring yaitu: jaringan internet yang tidak stabil dan tidak semua siswa memiliki handphone / gadget.
\end{abstract}

Kata kunci : Implementasi pembelajaran, model pembelajaran daring / online.

\begin{abstract}
This research is a descriptive qualitative research. This research was conducted at Cengkong II State Elementary School, Purwasari District, Karawang Regency. The subjects of this study were 3 people, namely the fourth grade teacher, 1 student and 1 student's parent. The object of this research is the online learning process during the covid-19 period. Data collection techniques used in this study were observation and interviews. The data collection instrument consisted of observations and interview guidelines. Data analysis was carried out descriptively by using the Miles and Humberman model data analysis technique.

The results from observations and interviews showed that the Cengkong II State Elementary School, Purwasari District, Karawang Regency during the covid-19 pandemic carried out distance learning (PJJ) using an online / online learning model. WhatsApp, Google Meet, Google Form, Zoom and Kine Master applications are applications that are used in the online learning process. Mobile phones, quotas and a strong and stable internet network are the main factors in the online learning process, in order to achieve teaching materials and learning objectives as long as the teacher explains and conveys the material that has been prepared. In addition, there are obstacles in the online learning process, namely: unstable internet network and not all students have cellphones / gadgets.
\end{abstract}




\section{Keywords: Implementation of learning, online learning model / online.}

\section{PENDAHULUAN}

Penerapan model pembelajaran menjadi salah satu faktor utama dalam proses pembelajaran. Hal tersebut dikarenakan ketika menerapkan model pembelajaran yang sesuai, maka proses pembelajaran dan hasil belajarnya pun akan sesuai dengan yang diharapkan. Model pembelajaran merupakan strategi dan seperangkat rencana pembelajaran yang dilakukan oleh guru dalam penyampaian materi pembelajaran.

Pembelajaran merupakan suatu kegiatan mengajar dan belajar, dimana mengajar seringkali disebut dengan guru yang memberikan suatu materi berupa pengetahuan, sikap dan keterampilan, sedangkan belajar adalah siswa yang menerima materi tersebut.Belajar merupakan sebuah aktivitas manusia yang secara terus-menerus akan dilakukan selama manusia tersebut masih hidup. Hal ini berarti menunjukkan bahwa belajar tidak pernah dibatasi oleh waktu, tempat maupun usia.

Proses pembelajaran dapat dilakukan dimanapun dan kapanpun, tidak hanya di dalam kelas saja namun diluar kelas bahkan dirumah pun kegiatan pembelajaran bisa terus berlangsung. Pemanfaatan teknologi informasi juga dapat membantu dalam proses pembelajaran, guru yang memanfaatkan teknologi informasi tersebut untuk melakukan suatu proses pembelajaran secara daring atau pembelajaran yang dilakukan tanpa melakukan tatap muka. Selama ini guru hanya berkutat pada metode pembelajaran konvensional saja, yaitu metode pembelajaran yang berlangsung secara tatap muka di kelas.

Dalam proses pembelajaran secara daring (Online) ini memberikan banyak sekali dampak, mulai dari dampak positif hingga dampak negatif. Pembelajaran secara daring (Online) ini guru dituntut untuk mempersiapkan pembelajaran sebaik dan sekreatif mungkin dalam memberikan suatu materi. Terutama dikalangan Sekolah Dasar (SD) atau di Madrasah Ibtidaiyah (MI) karena proses pembelajaran daring ini tidaklah mudah. Dalam proses pembelajaran daring (Online) ini tidak hanya melibatkan guru dan siswa saja, melainkan orang tua juga dituntut untuk terlibat dalam proses pembelajaran daring (Online) ini. Orang tua dengan latar pendidikan yang tinggi mungkin akan sangat mudah beradaptasi dalam proses pembelajaran secara daring. Namun, orang tua dengan latar belakang pendidikan yang minim mungkin jauh lebih sulit untuk beradaptasi dengan 
proses pembelajaran secara daring (Online) ini dikarenakan minimnya pengetahuan akan teknologi. Jaringan internet yang lemah juga menjadi salah satu faktor yang dapat menghambat proses pembelajaran daring (Online). Oleh karena itu, proses pembelajaran daring (Online) ini akan berjalan secara lancar jika kualitas jaringan internet tersebut lancar dan stabil. Proses pembelajaran secara daring (Online) ini juga membuat guru kesulitan dalam menyampaikan materi pembelajaran, dikarenakan tidak semua siswa berantusias dalam mengikuti proses pembelajaran secara daring (Online).

Berdasarkan hasil observasi dan wawancacara peneliti dengan Ibu Mera Rachmawati, S.Pd guru kelas IV Sekolah Dasar Negeri Cengkong II Kecamatan Purwasari Kabupaten Karawang, bahwa faktor utama yang sangat mempengaruhi proses pembelajaran secara daring (Online) ini adalah kekuatan jaringan internet serta faktor pendukungnya yaitu alat komunikasi seperti handphone yang memiliki fitur canggih, komputer atau laptop. Kualitas jaringan internet yang lemah membuat proses pembelajaran daring (Online) ini tidak berjalan secara maksimal. Akibatnya, beberapa siswa mengalami kesulitan dalam memahami materi pelajaran yang diberikan. Proses pembelajaran secara daring (Online) ini juga membuat guru kesulitan dalam mengukur sejauh mana siswa tersebut paham dengan materi yang diberikan.

\section{METODE PENELITIAN}

\section{Jenis Penelitian}

Dalam suatu penelitian diperlukan suatu pendekatan. Pendekatan yang digunakan dalam penelitian ini adalah pendekatan kualitatif. Pendekatan kualitatif adalah pendekatan yang menghasilkan prosedur analisis yang tidak menggunakan prosedur analisis statistik atau cara kuantifikasi lainnya. Sebagaimana yang didefinisikan oleh Herdiansyah H. (2012 : 4) bahwa Pendekatan kualitatif adalah suatu penelitian ilmiah yang bertujuan untuk memahami suatu fenomena dalam konteks sosial secara alamiah dengan mengedepankan proses interaksi komunikasi yang mendalam antara peneliti dengan fenomena yang diteliti.

Sedangkan metode dalam suatu penelitian merupakan salah satu cara yang 
ditempuh untuk mencapai suatu tujuan, sedangkan tujuan dalam sebuah penelitian adalah untuk mengungkapkan, menggambarkan dan mengumpulkan hasil pemecahan masalah melalui cara tertentu sesuai dengan prosedur penelitian yang dilakukan. Penjelasan menurut Sugiyono (2014: 2) bahwa metode penelitian pada dasarnya merupakan cara ilmiah untuk mendapatkan data dengan tujuan dan kegunaan tertentu.

Oleh karena itu, metode yang dipakai dalam penelitian ini menggunakan metode penelitian kualitatif deskriptif. Sebagaimana yang dikemukakan oleh Tohirin (2012: 3) yaitu suatu penelitian yang bermaksud memahami fenomena tentang apa yang dialami oleh subjek penelitian misalnya perilaku, persepsi, motivasi, tindakan, dan lain-lain secara holistik dan dengan cara deskripsi dalam bentuk kata-kata dan bahasa pada suatu konteks khusus yang alamiah serta dengan memanfaatkan berbagai metode alamiah dengan kata lain penelitian deskriptif, peneliti hendak menggambarkan suatu gejala (fenomena) atau sifat tertentu, tidak untuk mencari atau menerangkan keterkaitan antar variable. Sanjaya W. (2013: 59).

\section{Waktu dan Tempat Penelitian}

Penelitian ini dilaksanakan di Sekolah Dasar Negeri Cengkong II Kecamatan Purwasari Kabupaten Karawang. Adapun untuk pelaksanaan penelitian ini dilaksanakan pada tanggal 22 Juni sampai dengan tanggal 23 Juni 2021 di Sekolah Dasar Negeri Cengkong II Kecamatan Purwasari Kabupaten Karawang.

\section{Subjek Penelitian}

Untuk memperoleh data dari suatu penelitian diperlukan subjek dan sumber data. Sumber data dalam penelitian ini menurut Sugiyono (2015: 62), ada dua sumber data yaitu:

a. Sumber data primer adalah sumber data yang langsung memberikan data kepada 
pengumpul data.

b. Sumber data skunder merupakan sumber yang tidak langsung memberikan data kepada pengumpul data, misalnya lewat orang lain atau lewat dokumen.

Berdasarkan teori di atas, maka yang menjadi sumber data primer adalah Guru Kelas IV dan Siswa Kelas IV Sekolah Dasar Negeri Cengkong II Kecamatan Purwasari Kabupaten Karawang dengan hasil pengumpulan data melalui observasi dan wawancara. Sedangkan yang menjadi sumber data sekunder, yaitu data yang langsung dikumpulkan oleh peneliti sebagai penunjang dari sumber yang pertama. Dapat juga dikatakan data yang tersusun dalam bentuk dokumen-dokumen, dan dalam penelitian ini dokumentasi merupakan sumber data sekunder.

\section{Teknik Pengumpulan Data}

Teknik dalam pengumpulan data merupakan langkah paling strategis dalam penelitian, karena tujuan dari penelitian adalah mendapatkan data. Tanpa mengetahui teknik pengumpulan data, maka peneliti tidak akan mendapatkan data yang memenuhi standar yang ditetapkan. Dalam penelitian kualitatif, pengumpulan data dilakukan pada kondisi yang alamiah, sumber data primer, dan teknik pengumpulan data lebih banyak pada observasi berperan serta, wawancara mendalam dan dokumentasi.

Teknik pengumpulan data dalam penelitian ini adalah melalui observasi, wawancara dan dokumentasi. Sebagaimana yang dikatakan oleh Sugiyono (2015: 62) sebagai berikut: "Tehnik pengumpulan data dapat dilakukan dengan observasi (pengamatan), interview (wawancara), dokumentasi dan triangulasi (gabungan)”.

\section{Teknik Analisis Data}

Analisis data adalah proses mencari dan menyusun secara sitematis data yang diperoleh dari hasil wawancara, catatan lapangan, dan dokumentasi, dengan cara mengorganisasikan data ke dalam kategori, menjabarkan ke dalam unit-unit, melakukan 
sintesa, menyusun pola, memilih mana yang penting dan yang akan dipelajari, serta membuat kesimpulan sehingga mudah dipahami oleh diri sendiri maupun orang lain. Dalam penelitian kualitatif ini, peneliti menggunakan teknik analisis data deskriptif dalam menganalisis data hasil penelitiannya yang diperoleh dari proses mencari dan menyusun secara sistematis data yang diperoleh dari hasil observasi, wawancara, dan lapangan.

Miles and Huberman dalam (Sugiyono 2015: 91-99) mengemukakan bahwa aktivitas dalam analisis data kualitatif dilakukan secara interaktif dan berlangsung secara terus menerus sampai tuntas, sehingga datanya sudah jenuh. Aktivitas dalam analisis data, yaitu data reduction, data display, dan conclusion drawing atau verification.

\section{Data Reduction (Reduksi Data)}

Mereduksi data berarti merangkum data, memilih hal-hal yang pokok, memfokuskan hal-hal yan penting, dicari tema dan polanya. Dengan demikian data yang telah direduksi akan memberikan gambaran yang lebih jelas dan mempermudah peneliti untuk melakukan pengumpulan data selanjutnya dan mencarinya bila diperlukan. Setelah dilakukan reduksi data yang dianggap sudah falid, maka dilakukan pekerjaan selanjutnya yaitu penyajian data (data display).

\section{Data Display (Penyajian Data)}

Setelah data direduksi, maka selanjutnya adalah mendisplaykan data. Dalam penelitian kualitatif, penyajian data bisa dilakukan dalam bentuk uraian singkat, bagan dan hubungan anatar kategori, flowchart dan sejenisnya. Dalam hal ini Miles and Huberman menyatakan: "the most frequent from of display data for qualitative research data in the past has been narrative text". Yang paling sering digunakan untuk menyajikan data dalam penelitian kualitatif adalah dengan teks yang bersifat naratif.

\section{Conclusion Drawing/Verification}


Langkah ke tiga dalam analisis data kualitatif menurut Miles and Huberman adalah penarikan kesimpulan dan verifikasi. Kesimpulan awal yang dikemukakan masih bersifat sementara, dan akan berubah bila tidak ditemukan bukti-bukti yang kuat yang mendukung pada tahap pengumpulan data berikutnya. Tetapi apabila kesimpulan yang dikemukakan pada tahap awal, didukung oleh bukti-bukti yang valid dan konsisten saat peneliti kembali ke lapangan mengumpul data, maka kesimpulan yang dikemukakan merupakan kesimpulan yang kredibel.

\section{HASIL PENELITIAN DAN PEMBAHASAN}

\section{Hasil Penelitian}

Berdasarkan hasil penelitian yang dilakukan peneliti melalui wawancara kepada guru kelas, siswa dan orang tua siswa kelas IV Sekolah Dasar Negeri Cengkong II Kecamatan Purwasari Kabupaten Karawang mengenai implementasi model pembelajaran daring pada masa pandemi Covid-19, selanjutya yaitu menganalisis data yang terkumpul menggunakan metode penelitian kulaitatif deskfriptif secara terperinci.

\section{Implementasi Model Pembelajaran Daring Pada Masa Pandemi Covid-19}

\section{Responden 1 (R1)}

\section{Nama}

Jabatan

\section{Pendidikan Terakhir : S-1 PGSD}

Pembelajaran daring atau pembelajaran jarak jauh (PJJ) merupakan pembelajaran tanpa tatap muka secara langsung antara guru dengan siswa. Pembelajaran daring atau pebelajaran jaraj jauh (PJJ) ini dirasa sangat efektif untuk saat ini, guna memutus mata rantai penyebaran Virus Covid-19. Model pembelajaran yang tepat, yang diberikan oleh guru kepada siswa khususnya siswa sekolah dasar yaitu model pembelajaran yang 
menyenangkan, fleksibel, singjat dan mudah dipahami oleh siswa.

Model pembelajaran yang diterapkan oleh guru kelas IV SDN Cengkong II kecamatan purwasari Kabupaten Karawang dirasa sudah cukup efektif. Dikarenakan guru menggunakan video pembelajaran, penugasan tertulis dan praktik seperti yang dipaparkan oleh guru kelas IV sebagai berikut :

"Model pembelajaran daring yang digunakan yaitu video pembelajaran, penugasan tertulis dan praktik. Dalam praktik, siswa ditugaskan untuk membuat sebuah karya yang divideokan dan diperlihatkan hasilnya lalu dikirimkan ke guru kelas”.'

Pelaksanaan pembelajaran adalah suatu proses yang diatur sedemikian rupa menurut langkah-langkah yang disusun dalam rencana pelaksanaan pembelajaran (RPP) agar pelaksanaan mencapai hasil yang diharapkan. Rencana pelaksanaan pembelajaran (RPP) yang dibuat oleh guru selama masa pandemi ini sama dengan pembuatan RPP pada umumnya, namun dalam pembelajaran daring ini guru membuat RPP yang lebih ringkas yaitu penggunaan RPP daring satu lembar sesuai dengan anjuran yang diberikanoleh pemerintah. Dalam proses pembelajaran daring ini guru memberikan video pembelajaran kepada siswa setiap hari melalui aplikasi whatsapp dan melakukan reviewmateri melalui aplikasi google meet setiap minggunya, seperti yag dipaparkan oleh gurukelas IV sebagai berikut :

"Aplikasi yang digunakan dalam pelaksanaan pembelajaran daring yaitu, whatsapp, google meet dan google form, zoom. Whatasapp digunakan untuk mengirim video pembelajaran yang dibuat melalui aplikasi kine master, google form digunakan untuk memberikan soal latihan kepada siswa, dan google meet digunakan untuk mereview materi yang sudah diberikan kepada siswa dan zoom digunakan untuk mengawasi absensi dan keaktifan siswa dalam pembelajaran". 
Video pembelajaran yang diberikan oleh guru dibuat semenarik mungkin agar siswa tertarik dalam mengiktui proses pembelajaran secara daring ini. Guru juga dapat menggunakan bahasa yang sederhana dan mudah dimengerti agar siswa tidak kesulitan memahami materi yang diberikan oleh guru tersebut.

Pelatihan pembuatan video pembelajaran untuk guru juga sangat diperlukan, sekolah dapat memfasilitasi guru-guru dengan melakukan pelatihan pembuatan video pembelajaran yang menarik dengan menggunakan berbagai macam aplikasi, diantaranya guru dapat membuat video pembelaaran menggunakan aplikasi powtoon dan aplikasi sejenis lainnya, kemudian video pembelajaran tersebut dapat di upload ke youtube sebagai bahan ajar. Siswa dapat mengakses video pembelajaran tersebut melalui youtube dan dapat mendownloadnya untuk dipelajari secara ulang. Kurangnya pemahaman guru terhadap teknologi juga dapat menghambat keberhasilan pelaksanaan pembelajaran daring itu sendiri, penggunaan berbagai macam aplikasi untuk membuat video pembelajaran dirasa sangat penting.

Untuk menghasilkan video pembelajaran yang mampu meningkatkan motivasi dan efektifitas penggunaanya maka pengembangan video pembelajaran video harus memperhatikan karakteristik dan kriterianya, Riyana (2007:8-11) dalam Cintiasih T. yakni sebagai berikut :

\section{a. Clarity of Massage (Kejelasan Pesan)}

Dengan media video siswa dapat memahami pesan pembelajaran secara lebih bermakna dan informasi dapat diterima secara utuh sehingga dengan sendirinya informasi akan tersimpan dalam memori jangka Panjang dan bersifat retensi.

\section{b. Stand Alone (Berdiri Sendiri)}

Video yang dikembangkan tidak bergantung pada bahan ajar lain atau tidak harus 
digunakan Bersama-sama dengan bahan ajar lain.

c. User Friendly (Bersahabat/akrab dengan pemakainya)

Media video menggunakan Bahasa yang sederhana, mudah dimengerti dan menggunakan bahasa yang umum. Paparan informasi yang ditampilkan bersifat membantu dan bersahabat dengan pemakainya, termasuk kemudahan pemakai dalam merespon, mengakses sesuai dengan keinginan.

d. Representasi isi

Materi harus benar-benar representative, misalnya materi simulasi atau demonstrasi. Pada dasarnya materi pelajaran baik social maupun sains dapat dibuat menjadi media video.

e. Visualisasi dengan media

Materi dikemas secara multimedia terdapat didalamnya teks, animasi, sound dan video sesuai tuntutan materi. Materi-materi yang digunakan bersifat aplikatif, berproses, sulit terjangkau berbahaya apabila langsung dipraktikan, memiliki tingkat keakurasian tinggi.

f. Menggunakan kualitas resolasi yang tinggi

Tampilan berupa grafis media video dibuat dengan teknologi rekayasa digital dangan resolusi tinggi tetapi support untuk setiap spech sistem komputer.

g. Dapat digunakan secara klasikal atau individual

Video pembelajaran dapat digunakan oleh para siswa secara individual, tidak hanya dalam setting sekolah, tetapi juga dirumah.

Dapat pula digunakan secara klasikal dengan jumlah siswa 50 orang bia dapat 
dipandu oleh guru atau cukup mendengarkan uraian narasai dari narrator yang telah tersedia dalam program.

Sejalan dengan A. Kurniawati, dkk (2013) menjelaskan bahwa, media video mampu menarik perhatian siswa, meningkatkan daya imajinasi siswa, meningkatkan daya berpikir kritis dan memicu siswa untuk lebih berpartisipasi serta antusias, sehingga nantinya siswa dapat lebih aktif dalam proses pembelajaran. Selain itu, media video memiliki fungsi untuk menghadirkan sesuatu yang konkrit, meskipun tidak berbentuk fisik. Belajar dengan menggunakan indera ganda penglihatan dan pendengaran dapat memberikan keuntungan bagis siswa untuk lebih memahami materi yang dijelaskan oleh guru.

Penilaian adalah bagian yang sangat penting di dalam dunia pendidikan, karena penilaian merupakan bahan evaluasi selama proses pembelajaran. Evaluasi yang dilaksanakan dalam proses pembelajaran daring yaitu dengan pemberian tugas kepada siswa dalam bentuk tertulis maupun dalam bentuk video, seperti yang telah diungkapkan dalam wawancara peneliti dengan guru kelas IV sebagai berikut:

"Di nilai sesuai dengan hasil kerja siswa dan pengumpulan tugas dengan bentuk video".

Kunci penting dalam keberhasilan pembelajaran daring ini adalah komunikasi antar wali kelas dengan orang tua siswa, karena dalam proses pembelajaran ini siswa tidak dapat bertatap muka langsung dengan guru, maka orang tua yang menjadi guru utama dirumah. Berbagai macam latar belakang pekerjaan orang tua siswa membuat pembelajaran daring itu sendiri menjadi kurang maksimal, dikarenakan orang tua siswa tidak dapat mendampingi anaknya dalam mengikuti pembelajaran daring sehingga berdampak pada kurangnya efektifitas dan efisiensi waktu dalam proses pembelajaran 
daring. Guru diharuskan untuk selalu siap mendampingi siswa dari pagi hingga malam hari. Hal ini berkaitan dengan kinerja guru, dimana yang seharusnya guru mempersiapkan materi untuk hari berikutnya namun guru masih merasa terbebani oleh materi yang belum tuntas dihari tersebut.

Perencanaan merupakan hal yang sangat penting untuk dilaksanakan di lembaga pendidikan. Tanpa adanya perencanaan, sekolah bisa jadi mengalami kesulitan dalam mewujudkan tujuan yang ingin dicapai. Dengan adanya perencanaan, pekerjaan dapat lebih terarah dan jelas. Perencanaan pembelajaran daring secara terstruktur dapat mempengaruhi keberhasilan dalam melakukan proses pembelajaran daring tersebut. Keberhasilan proses pembelajaran daring tersebut dapat dilihat dari persentase antusias siswa dalam mengikuti pembelajaran. Minimnya persentase antusias siswa sangat mempengaruhi pemahaman siswa dalam mengikuti pembelajaran, yang dibuktikan oleh hasil wawancara dengan guru kelas IV SDN Cengkong II sebagai berikut:

"Antusias siswa dalam mengikuti pembelajaran daring hanya sekitar 45\% saja dan sejauh ini hanya $45 \%$ sampai dengan 50\% saja dari jumlah siswa kelas IV yang mampu memahami materi pembelajaran melalui pembelajaran daring selama masa pandemi ini”.

Minimnya persentase antusias dan pemahaman siswa dalam memahami materi tersebut menunjukan bahwa kurang dari setengah siswa kelas IV yang mampu memahami materi yang diberikan oleh guru melalui pembelajaran daring. Hal ini dapat disebabkan oleh kurang terstrukturnya pembelajaran daring dan video pembelajaran yang diberikan oleh guru kurang menarik. Dalam pembelajaran 63 daring, guru dituntut untuk kreatif dan inovatif dalam membuat video pembelajaran guna menarik antusias siswa agar lebih bersemangat dan tertarik untuk mengikuti pembelajaran daring. 
Pembelajaran terstruktur merupakan seperangkat tindakan yang dirancang untuk proses belajar peserta didik dengan mempertimbangkan kejadian-kejadian internal yang berlangsung didalam peserta didik. Proses pembelajaran yang berhasil guna memerlukan teknik, metode, dan pendekatan tertentu sesuai dengan karakteristik tujuan, peserta didik, materi dan sumber ajar, sehingga diperlukan strategi yang tepat (Nurmin Lasapa dkk, 2017).

Pembelajaran terstruktur adalah bentuk pembelajaran sistematis, dalam pelaksanaan pembelajaran terstruktur, guru menyampaikan tujuan yang ingin dicapai dalam proses itu. Dapat juga pembelajaran terstruktur ini disebutkan sebagai pembelajaran yang berorientasi pada tujuan yang ingin dicapai (Ummu Nadifah, 2018).

Dalam mengimplementasikan pembelajaran daring tentu berbeda dengan pengimplementasian pembelajaran secara langsung tatap muka didalam kelas. Dalam mengimplementasikan pembelajaran daring, guru tertentu harus melibatkan orang tua, dimana peran orang tua adalah kunci sukses dari proses pembelajaran daring itu sendiri. Dalam pembelajaran daring pun, diperlukan kualitas sinyal 64 bytes yang stabil. Maupun kuota internet yang memadai guna menunjang keberhasilan pembelajaran daring.

Adapun faktor pendukung dalam pembelajaran daring yaitu, sekolah memfasilitasi wifi untuk guru sebagai sarana untuk memberikan materi pembelajaran daring selama guru masih berada dilingkungan sekolah. Namun jaringan wifi tersebut hanya bisa digunakan ketika guru masih didalam lingkungan sekolahan. Hal ini membuat guru harus mengeluarkan biaya sendiri untuk membeli kuota internet di luar jam pembelajaran. Dan pendukung lainnya dalam pembelajaran daring yaitu, sekolah memfasilitasi kuota internet setiap bulannya kepada siswa. Akan tetapi pihak sekolahan tidak dapat mengontrol penggunaan kuota internet tersebut. 


\section{Responden 2 (R2)}

Nama

Jabatan

\section{: Khalifatul Aula}

\section{: Siswa Kelas IV SDN Cengkong II}

\section{Pendidikan Terakhir : PAUD}

Pembelajaran pada masa pandemi covid-19 dilakukan dengan sistem pembelajaran jarak jauh (PJJ) yang dilakukan secara daring atau online melalui aplikasi whatsapp, google form dan zoom. Kurangnya kemampuan menggunakan aplikasi tersebut mengakibatkan siswa tidak mengerti cara menggunakannya. Pemberian tugas yang diberikan oleh guru melalui whatsapp grup dengan memfoto tugas yang akan diberikan, membuat video dan pesan suara (voice note), seperti yang dipaparkan oleh siswa kelas IV sebagai berikut :

"Setiap 1 minggu sekali tugas yang diberikan oleh guru dikumpulkan setiap pembelajaran home visit".

Pembelajaran daring tentunya harus memiliki sinyal atau jaringan internet yang kuat, sehingga proses pembelajaran daring dilaksanakan dengan maksimal. Dan orang tua juga tidak dapat setiap saat mendampingi anaknya, sehingga semangat belajar menurun, seperti yang dipaparkan siswa kelas IV sebagai berikut :

\section{"Kurangnya semangat dalam belajar".}

Pembelajaran daring ini, memerlukan handphone atau tablet sebagai alat pembelajaran daring, kuota dan jaringan internet yang kuat dan stabil agar penyampaian materi yang diberikan oleh guru dapat diterima dengan baik.

Menurut siswa kelas IV Sekolah Dasar Negeri Cengkong II, faktor pendukung pembelajaran daring yaitu :

"Adanya handphone, kuota dan jaringan internet merupakan faktor pendukung 
pembelajaran daring”.

\section{Responden 3 (R3)}

\section{Nama \\ : Dinda Puteri \\ Jabatan \\ : Orangtua Siswa Kelas IV \\ Pendidikan Terakhir : SMA}

Implementasi pembelajaran pada masa pandemi covid-19 dilakukan dengan sistem pembelajaran jarak jauh (PJJ). Dengan sistem pembelajaran jarak jauh (PJJ), pembelajaran dilakukan secara daring atau online melalui aplikasi whatsapp, google form dan zoom. Kurangnya kemampuan menggunakan aplikasi tersebut mengakibatkan orang tua siswa tidak mengerti cara menggunakan aplikasi tersebut yang berdampak kepada anaknya karena penyanmpaian materi pembelajaran yang tidak sepenuhnya sesuai dengan yang diberikan guru, seperti yang dipaparkan oleh orang tua siswa kelas IV sebagai berikut :

"Kurang dimengerti karena pembelajaran sulit diterima".

Pemberian tugas dilakukan melalui pesan whatsapp grup yang dikerjakan dengan memfoto tugas yang akan diberikan, membuat video dan pesan suara (voice note), tentunya dengan melihat Renacana Pelaksanaan Pembelajaran (RPP).

Dalam pembelajaran daring tentunya harus memiliki sinyal atau jaringan internet yang kuat, sehingga proses pembelajaran daring dilaksanakan dengan maksimal. Menurunnya semangat anak dalam mengikuti pembelajaran, karena orang tua tidak dapat setiap saat mendampingi anaknya untuk menjelaskan pembelajaran yang berbasis teknologi yang terkendala oleh pekerjaan-pekerjaan lainnya, seperti yang dipaparkan oleh orang tua murid kelas IV sebagai berikut :

"Kendala jaringan internet, kurangnya semangat anak dalam belajar, orang tua 
tidak dapat setiap saat mendampingi saat pembelajaran daring”.

Kemajuan teknologi merupakan salah satu yang menjadikan kita bisa mengetahui apa yang tidak kita ketahui secara jarak jauh. Begitupun dengan pembelajaran daring ini, yang memerlukan handphone atau tablet sebagai alat pembelajaran daring, kuota dan jaringan internet yang kuat dan stabil agar penyampaian materi yang diberikan oleh guru dapat diterima dengan baik. Oleh karena itu, dalam menyajikan pembelajaran secara daring, guru harus variatif dan inovatif agar siswa tidak jenuh. Sehingga antusias dan semangat anak tetap stabil dan bisa memberikan prestasi yang baik meski dalam keadaan pandemi covid-19 ini.

Guru melakukan home visit selama 1 bulan 2 kali pertemuan dengan membagi kelompok, setiap kelompok terdiri dari 4 orang. Home visit merupakan salah satu model pembelajaran yang efektif guna memutus rantai virus covid-19. Handphone, kuota dan jaringan internet merupakan faktor pendukung pembelajaran daring.

\section{Pembahasan}

\section{Implementasi Pembelajaran Daring Pada Masa Pandemi Covid-19 Sekolah Dasar}

\section{Negeri Cengkong II.}

Dari hasil wawancara dan observasi diperoleh gambaran bahwa Sekolah Dasar Negeri Cengkong II Kecamatan Purwasari Kabupaten Karawang pada masa pandemi covid-19 melakukan pembelajaran jarak jauh (PJJ) dengan menggunakan model pembelajaran daring atau online. Aplikasi whatsapp, google meet, google form dan zoom adalah aplikasi yang digunakan dalam proses pembelajaran daring. Namun dalam proses pembelajaran daring terdapat kendala yaitu : jaringan internet yang tidak stabil dan tidak semua siswa memiliki gadget. Tetapi bagi guru aplikasi-aplikasi tersebut, memudahkan guru dalam menjelaskan, menyampaikan materi ajar dan memberikan latihan soal serta 
memberikan tugas kepada siswa.

Dalam pemberian materi yang diberikan guru sesuai dengan kurikulum pada masa pandemi covid-19 yang disusun didalam Rencana Pelaksanaan Pembelajaran (RPP) satu lembar. Upaya yang dilakukan guru untuk mengimplementasikan pembelajaran daring pada masa pandemi covi-19 yaitu dengan cara membuat video pembelajaran sesuai materi ajar. Membuat dan mengedit video dengan menggunakan aplikasi kine master.

\section{Faktor Penghambat Implementasi Pembelajaran Daring Pada Masa Pandemi}

\section{Covid-19 Sekolah Dasar Negeri Cengkong II.}

Dalam proses pembelajaran daring tentunya harus memiliki handphone/gadget, kuota dan jaringan internet yang tidak stabil serta keawaman orang tua dalam menggunakan handphone/gadget. Maka dari itu, solusi untuk mengatasi kendala tersebut guru membuat kelompok belajar dengan tetap mematuhi protokol kesehatan yang beranggotakan satu kelompok belajar maksimal 5 orang siswa, yang nantinya guru akan mengadakan home visit selama satu kali pertemuan dalam satu minggu.

Kurangnya daya serap siswa dalam mengikuti pembelajaran daring. Disebabkan siswa kurang mampu memahami apa yang disampaikan guru karena keterbatasan sarana. Sehingga menurunnya semangat dan antusias siswa dalam pembelajaran daring mengakibatkan kurang mencapai kriteria ketuntasan minimum.

\section{Faktor Pendukung Pembelajaran Daring Pada Masa Pandemi Covid-19 Sekolah Dasar Negeri Cengkong II.}

Handphone, kuota dan jaringan internet yang stabil merupakan faktor utama dalam proses pembelajaran daring, agar tercapainya materi ajar dan tujuan pembelajaran selama guru menjelaskan dan menyampaikan materi yang telah disiapkan. Akan adanya informasi yang tidak valid mengenai materi ajar jika faktor utama dalam pembelajaran 
daring tidak terpenuhi. Maka dari itu guru membuat solusi bagi siswa yang tidakmemiliki handphone/gadget tersebut dengan cara membuat kelompok belajar satu kelompok terdiri atas 5 orang siswa. Bagi siswa yang tidak memiliki handphone/gadget dikelompokkan dengan siswa yang memiliki hanphone/gadget, sehingga informasi yang diterima akan sama.

\section{KESIMPULAN DAN IMPLIKASI}

\section{Kesimpulan}

Berdasarkan hasil penelitian yang telah dilakukan Proses pembelajaran guru berubah yang biasanya pembelajaran dilaksanakan secara langsung menjadi pembelajaran daring / online. Implementasi pembelajaran pada masa pandemi covid-19 pada kelas IV Sekolah Dasar Cengkong II yaitu dengan memanfaatkan beberapa macam jenis aplikasi seperti whatsapp, google form, google meet, zoom dan kine master untuk membuat video pembelajaran. Guru membuat video pembelajaran dan mengirimkannya melalui aplikasi whatsapp agar siswa dapat membuka kembali materi pembelajaran yang diberikan oleh guru dan mempelajarinya secara ulang.

\section{Implikasi}

Saran yang terkait tentang upaya guru dalam implementasi pembelajaran daring/online adalah sebagai berikut :

1. Kepada peserta didik, agar tetap selalu bersemangat dalam mengikuti proses pembelajaran secara daring / online.

2. Kepada guru, agar tetap selalu membimbing dan mendampingi dengan sabar serta membuat video pembelajaran semenarik mungkin agar siswa lebih tertarik dalam mengikuti proses pembelajaran secara daring / online. 


\section{DAFTAR PUSTAKA}

A. Kurniawati, dkk. (2013). Implementasi Metode Penugasan Analisis Video pada Materi Perkembangan Kognitif, Sosial dan Moral. Jurnal Pendidikan IPA Indonesia, Volume 2, Nomor 2.

Arifin, Z. (2013). Evaluasi Pembelajaran. Bandung: Remaja Rosdakarya.

Fathurrohman, Muhammad dan Sulistyorini. (2012). Implementasi Manajemen Peningkatan Lembaga Pendidikan Islam Secara Holistik. Yogyakarta: Teras.

Hadisi dan Muna. (2015) Pengelolaan teknologi informasi dalam menciptakan model inovasi pembelajaran (E-Learning). Jakarta: Bumi Aksara.

Herdiansyah H. (2012). Metodologi Penelitian Kualitatif untuk Ilmu-Ilmu Sosial. Jakarta : Salemba Humanika.

Lasapa, Nurmin, Achmad Ramadhan dkk. (2017). Meningkatkan Pemahaman Konsep Struktur Dan Fungsi Bagian Tumbuhan Melalui Pendekatan Kontekstual Pada Siswa Kelas IV SD Inpres 2 Sidole. Jurnal Kreatif Online, Volume 05, Nomor 02.

Mulyadi, D. (2015). Studi Kebijakan Publik dan Pelayanan Publik: Konsep dan Aplikasi Proses Kebijakan Publik dan Pelayanan Publik. Bandung: Alfabeta CV.

Mulyasa. (2010). Implementasi Kurikulum Satuan Pendidikan. Jakarta: Bumi Aksara.

Nadifah, U. (2018). Pembelajaran Terstruktur Dengan Pemberian Tugas Dalam Meningkatkan Prestasi belajar Ilmu Pengetahuan Sosial Pada Siswa Kelas IIIA MIN Klangenserut Tahun Pelajaran 2015/2016. Jurnal Ilmiah Pengembangan Pendidikan, Volume 5, Nomor 2.

Naditya, Rochyani, Suryono, Agus dan Rozikin, Mochamad. (2013). Implementasi Peraturan Daerah Kota Malang Nomor 10 Tahun 2010 Tentang Pengelolaan Sampah (Suatu Studi Di Dinas Kebersihan Dan Pertamanan (DKP) Dalam Pelaksanaan Program Bank Sampah 69 Malang (BSM) Di Kelurahan Sukun Kota Malang). Jurnal Administrasi Publik (JAP), Volume 1, Nomor 6.

Purwanto, A., \& Parnomo, R., Asbari, M., Santoso, P. B., Wijayanti, L. M., Hyun, C. C., \& Putri, R. S. (2020). Studi Eksploratif Pandemi COVID-19 TerhadapProses Pembelajaran Online Di Sekolah Dasar. Journal Of Education,Psychology And Counseling.

Rachmawati, Tutik dkk. (2015). Teori Belajar dan Proses Pembelajaran yang Mendidik. Yogyakarta: Gava Media.

Rusman., Kurniawan D, dan Riyana C. (2012). Pembelajaran Berbasis Komputer: 
Harmawati, Tia Latifatu Sa'diah, Nadiya Angraeni

Vol 6 No 1

ISSN : 2541-6995

E ISSN : 2580-5517

Mengembangkan Profesionalisme Abad 21. Bandung: Alfabeta.

Rusman. (2014). Model-model Pembelajaran (Mengembangkan Profesionalisme

Guru). Jakarta: Raja Grafindo Persada.

Sanjaya W. (2013). Penelitian Pendidikan : Jenis, Metode, dan Prosedur, Jakarta : Kencana Prenada Media Group.

Sugiyono. (2015). Metode Penelitian Kuantitatif Kualitatif dan R\&D. Alfabeta

Suharsimi, A. (2013). Dasar-Dasar Evaluasi Pendidikan. Jakarta: Bumi Aksara.

Taufik, Mhd. dan Isril. (2013). Implementasi Peraturan Daerah Badan Permusyawaratan Desa. Jurnal Kebijakan Publik, Volume 4, Nomor 2.

Tohirin. (2012). Metode penelitian Kualitatif dalam Pendidikan dan Bimbingan

Konseling. Jakarta : PT Raja Grafindo Persada.

Trianto. (2010). Model Pembelajaran Terpadu. Jakarta: Bumi Aksara 